\title{
Wspólna struktura ludzkich dociekań w pragmatyce komunikacji prawniczej
}

\author{
The common structure of human inquiry in the pragmatics of legal communication
}

\author{
Joanna OSIEJEWICZ \\ Uniwersytet Warszawski/ University of Warsaw \\ E-mail: j.osiejewicz@uw.edu.pl,
}

\begin{abstract}
A lawyer who wants to go beyond matrix thinking must develop some mental and practical agility. Understanding and applying John Dewey's experimental logic allows this agility to be achieved. His concept of experimental logic assumes that creativity and subjectivity are the foundation of the functioning of a complex system of legal institutions. Dewey introduces the concept of a common structure or pattern of human inquiry, which remains largely the same regardless of the issue to which it is applied. The pragmatic pattern of legal reasoning is therefore based on a more general pattern of human reasoning. The purpose of the article is to discuss this concept and to present its assumptions in relation to legal reasoning and legal communication.
\end{abstract}

Keywords: legal communication, experimental logic, legal analysis, legal reasoning, pragmatics

\section{Wstęp}

W krótkim eseju zatytułowanym „Logical Method and the Law” J. Dewey przedstawił koncepcję, zmierzającą do zaoferowania osobom zaangażowanym w proces podejmowania decyzji prawnych jednolitego sposobu traktowania spraw służących określonym celom, mimo różnorodności tych spraw (J. Dewey 1924: 22). Zdaniem J. Deweya, urzędnicy administracyjni, sędziowie i prawnicy powinni ufać logice eksperymentalnej i kierować się ogólnymi zasadami uznanymi za przydatne dla rozwiązywania konkretnych problemów prawnych. Innymi słowy, analizując konsekwencje rozumowania prawniczego w zakończonych już sprawach, prawnik może sformułować lepsze decyzje w sprawach, nad którymi pracuje obecnie.

J. Dewey uważał, że system analityczny, który stoi za prawem, jest konsekwencjonalistyczny. To oznacza, że analiza prawnicza i komunikacja w tym systemie mają być ukierunkowane na produkty końcowe, a nie na proces, który prowadzi do tych produktów. Takie stanowisko jest o tyle uzasadnione, że codzienne działanie systemu prawnego wydaje się opierać na praktycznych aspektach tego, jak prawnicy radzą sobie z konkretnymi sprawami w konkretnych sytuacjach faktycznych. Celem artykułu jest omówienie koncepcji J. Deweya, ukazanie jej założeń w odniesieniu do rozumowania prawniczego i uzasadnienie, ukazanie eksperymentalnego podejścia do rozwiązywania problemów prawnych oraz komunikowania tych rozwiązań. 


\section{Eksperymentalne rozumowanie prawnicze}

Logika eksperymentalna opisywana przez J. Deweya obejmuje proces prób i błędów, który zmienia się w zależności od okoliczności rozumowania, a nawet od tego, kto jest $\mathrm{w}$ proces rozumowania zaangażowany. Kiedy aktorzy w systemie prawnym angażują się w proces eksperymentalnych dociekań, badają, oceniają i wartościują dane, które mają do dyspozycji, wykorzystując elementy, które ich zdaniem działają, i odrzucając te, które ich zdaniem są nieprzydatne. Prawnicy poszukują teorii pasujących do prowadzonych przez nich spraw i odnoszących się do ich problemów prawnych, oceniają powiązanie tych teorii z proponowanymi wynikami i kalkulują, czy teorie będą prowadzić do pożądanego rezultatu. Jeśli prowadzą one lub mogą prowadzić do pożądanych rezultatów, prawnicy wykorzystają je jako narzędzia analityczne (M. Mendell 1994: 576-635). Jeśli nie, odrzucą je na rzecz właściwszych teorii, bardziej pomocnych w danej sprawie. Jeśli przed ostatecznym rozwiązaniem sprawy konieczne będzie rozstrzygnięcie kilku problemów pośrednich, omówiony proces kształtowania zagadnień i stosowania odpowiednich regulacji będzie postępował odrębnie dla każdego problemu, tak długo aż sprawa zostanie dostatecznie rozwiązana (J. Dewey 1938: 108). J. Dewey zaczął szczegółowo omawiać poszczególne aspekty logiki eksperymentalnej i jej zastosowanie w sferze rozumowania prawniczego nie dlatego, że uznał za konieczne przekonanie decydentów prawnych do zmiany ich rozumowania, ale dlatego, że uważał, że już działają oni w ten sposób. Był zdania, że decydenci utrzymują fikcję w celu ukrycia zasad faktycznie stosowanych w procesie podejmowania decyzji prawnych przez ogół społeczeństwa (J. Dewey 1924: 23-26). Ta fikcja wyraża się $\mathrm{w}$ twierdzeniu, że decyzje prawne muszą być podejmowane zgodnie ze ściśle formalnymi zasadami logiki, mającymi sylogistyczny charakter (J. Dewey 1924: 21).

Dewey uważał, że logika, która ma największą wartość historyczną i wywiera największy wpływ na decyzje prawne, wynika z sylogizmu (więcej: J. Osiejewicz 2020). Jest to jednak logika ustalonych form, a nie metod podejmowania inteligentnych decyzji w konkretnych sytuacjach lub metod stosowanych w kwestiach spornych (J. Dewey 1924: 21). Dewey wątpił, aby taka logika mogła faktycznie stanowić serce wysoko rozwiniętego systemu prawnego (B. Bix 2004: 80-81). Jego zdaniem oparte na niej rozumowanie prawnicze prowadzi do mechanicznego orzecznictwa, w którym przepisy prawne są automatycznie stosowane do sytuacji faktycznych w taki sposób, aby z absolutną logiczną pewnością określić właściwą decyzję. Według J. Deweya ten rodzaj sylogistycznego rozumowania w prawie nie jest ani możliwy, ani pożądany. J. Dewey nie zaprzeczał, że duch formalnej logiki Arystotelesa ma związek z jego teorią logiki eksperymentalnej. Nie zgadzał się jednak ze ścisłym stosowaniem formy sylogistycznej. Jego zdaniem istnieje dysproporcja między faktycznym rozwojem prawnym a ścisłymi wymogami logiki opartej na sylogizmie (J. Dewey 1924: 20).

J. Dewey utożsamiał pragnienie formalności logicznej z potrzebą dążenia do spójności W. Muyumb (2014: 159-173). Wykorzystanie wcześniej przygotowanych i znanych pojęć daje bowiem poczucie stabilności: gwarancji ochrony przed nagłymi i arbitralnymi zmianami reguł, które determinują konsekwencje działań (J. Dewey 1938: 134-135). J. Dewey uważał jednak, że jest to iluzoryczne poczucie ochrony, które 
utrwala się dzięki raz przyjętemu nawykowi (J. Dewey 1924: 20). Obowiązek wykazywania formalnej, sylogistycznej spójności logicznej w procesie podejmowania decyzji prawnych wynika bowiem z nawyku, napędzanego własną wewnętrzną bezwładnością. Zdaniem J. Deweya istnieje inny rodzaj logiki w pracy prawnika: logika dotycząca konsekwencji (N. MacCormick 1983: 242).

Próbując wyjaśnić swój alternatywny pogląd, J. Dewey zdefiniował teorię logiczną jako procedurę stosowaną przy podejmowaniu decyzji w tych sprawach, w których późniejsze doświadczenia pokazują, że były to najlepsze decyzje, jakie można było podjąć w danych warunkach (J. Dewey 1924: 17-18). Taka definicja pozwala na racjonalizację poprzednich decyzji. Zdaniem Deweya reguły prawne powinny przede wszystkim tworzyć uogólnione systemy logiczne, których podstawą jest spójność w stosowaniu prawa. Przyznawał wprawdzie, że istnieją sytuacje, w których logika formalna może być stosowana w rozumowaniu prawniczym, utrzymywał jednak, że formalna spójność logiczna nie powinna być głównym celem systemu prawnego. Logika formalna powinna być stosowana o tyle, o ile służy pragmatycznemu podejmowaniu decyzji. Konsekwentnie argumentował, że najważniejsze jest podjęcie właściwej decyzji prawnej, niezależnie od logiki formalnej.

Dewey zaprzeczał, jakoby logika Arystotelesa była podstawą do zrozumienia prawa. Dla Deweya logika stanowi narzędzie intelektualnego sondażu, analizy i wglądu w sytuację. Może być ona modyfikowana, podobnie jak inne narzędzia stosowane w nowych warunkach do osiągnięcia nowych celów. Stałe i uniwersalne rozumienie logiki byłoby nadmiernie restrykcyjne, ponieważ argumenty lub zasady logicznie spójne w rozumieniu arystotelesowskim nie mogłyby zmieniać się w czasie. Zasady logiczne - niezależnie od formy - są narzędziami, które nigdy nie mają stać się absolutnie statyczne. Muszą one być przede wszystkim przydatne w praktyce, aby ich stosowanie było uzasadnione (J. Dewey 1924: 26). W zakresie, w jakim nie są one użyteczne, należy je odrzucić na rzecz bardziej odpowiednich zasad. Traktowanie zasad prawnych jako abstrakcyjnych dyrektyw przynosi efekt przeciwny do zamierzonego - czyni prawo mechanicznym i oderwanym od swej funkcji społecznej.

\section{Wspólna struktura lub wzorzec ludzkich dociekań}

J. Dewey (1938: 105) uważał, że rozumowanie prawnicze odzwierciedla zjawisko, które nazwał ,wspólną strukturą lub wzorcem ludzkich dociekań”. Jego zdaniem rozumowanie prawnicze oparte jest na ogólnym paradygmacie ludzkiego myślenia: człowiek wykorzystuje swoje, ,renesansowe" zdolności w podobny sposób, bez względu na to, w jakie przedsięwzięcia jest zaangażowany. Struktura rozumu nie jest bowiem, jak niektórzy mogliby przypuszczać, stała i abstrakcyjna. Dewey rozstał się z racjonalistyczną tradycją filozoficzną reprezentowaną przez Rene Descartesa i Immanuela Kanta i przyjął bardziej płynną i praktyczną formę myślenia (R. Rorty 1982: 161), zaprojektowaną w taki sposób, aby zmierzać prostą drogą do praktycznych rezultatów, a nie abstrakcyjnych pojęć umysłu lub poznania, rozwiniętych przez innych epistemologów i logików. Mówiąc prostym językiem, myślenie jest dobre, jeśli działa. Działa zaś wtedy, gdy dzięki niemu człowiek osiąga to, co chce osiągnąć. Dewey nie zgadzał się z tradycją racjonalistyczną, podkreślającą, że istnieją zamknięte, 
stałe i prawdziwe formy intuicji i logiki, na których opiera się ludzki umysł. Rozumowanie prawnicze w rozumieniu J. Deweya oznacza zastosowanie wspólnego wzoru ludzkiego rozumowania do określonej dziedziny intelektualnej, w tym przypadku prawa. Wzorzec rozumowania prawniczego jest więc oparty na bardziej ogólnym wzorcu rozumowania ludzkiego (J. Dewey 1938: 105). Aktorzy w systemie prawnym wykorzystują swoje zdolności analityczne do rozstrzygania problemów prawnych w ramach społeczności dyskursu prawnego. Ta kontekstowa aplikacja jest konsekwencją pragmatycznej natury ludzkiego rozumowania.

Rozumowanie we wszelkich obszarach ludzkiej aktywności intelektualnej, w tym rozumowanie prawnicze, rozpoczyna się od potwierdzenia istnienia nieokreślonej sytuacji. Rozpoznanie, że istnieje nieokreślona sytuacja, to pierwszy krok w dociekaniach. Chodzi tu o wyłonienie takiej nieokreślonej sytuacji, co do której należy uznać, że może się do niej odnosić system prawny. Oznacza to, że cały proces kognitywny zależy od rozpoznania, że mamy do czynienia z problemem prawnym, w odróżnieniu od problemu politycznego, naukowego, społecznego lub technicznego (patrz R.E. Neustadt/ E.R. May 1986).

Gdy nieokreślona sytuacja zostanie uznana za problem prawny, a tym samym umieszczona $\mathrm{w}$ odpowiednim polu odniesienia, można kontynuować proces rozumowania. Na tym etapie należy wziąć pod uwagę ewentualne uprzedzenia (J.W. Rand 2003: 731). Jak twierdzi J. Dewey, prawnik wychodzi od niejasnego oczekiwania pewnego wniosku lub co najmniej alternatywnych wniosków, a następnie poszukuje zasad i danych, które dany wniosek potwierdzą lub które pozwolą wybrać między wnioskami konkurencyjnymi. Prawnik rozpoczyna zatem od „niejasnego wniosku”, do którego zamierza dojść, oczywiście z korzyścią dla klienta, a następnie analizuje fakty tak, aby zidentyfikować informacje, na podstawie których można skonstruować korzystne stwierdzenia o faktach i sformułować przesłankę. Jednocześnie szuka reguł prawnych stosowanych $w$ podobnych sprawach oraz zasad uzasadniających określoną perspektywę i sposób interpretowania faktów.

Gdy tylko problem prawny zostanie zidentyfikowany i zacznie się kształtować w określoną kwestię prawną, kolejnym krokiem jest naświetlenie prawdopodobnego wniosku lub wniosków, które rozwiążą daną sytuację (J. Dewey 1938: 105). Ten niejasny wniosek, o którym mówi J. Dewey, jest w dużej mierze zdeterminowany przez wynik, który będzie najkorzystniejszy dla konkretnego klienta danego prawnika w kontekście napotkanego problemu prawnego. Opierając się w dużej mierze na uprzedzeniach co do prawdopodobnych (lub przynajmniej możliwych) wyników rozumowania, osoba podejmująca decyzje prawne ujmuje problem prawny w sposób sprzyjający początkowym, niejasnym wnioskom. Jak twierdzi Dewey, sposób, w jaki powstaje problem, jest decydujący dla przyjęcia lub odrzucenia konkretnych opcji (J. Dewey 1938: 112). W konsekwencji, sposób, w jaki początkowo kształtuje się kwestia prawna, bardzo często decyduje o wyniku sprawy, ponieważ już na tym etapie podejmowana jest decyzja o stosowanym prawie (J. Dewey 1924: 23). Prawo stosuje się do faktów, a sposób, w jaki fakty w danej sprawie są organizowane lub też wyrażane, określają przepisy prawa, które będą miały zastosowanie $\mathrm{w}$ danej sprawie (J. Dewey 1924: 23-26). Dlatego tak istotne jest jak najdoskonalsze uporządkowanie 
faktów, które pozwoli na wykorzystanie do nich najkorzystniejszych regulacji prawnych.

Dla Deweya (i innych pragmatyków; B.H. Levy 1991: 123 i nast.) ludzkie rozumowanie jest systemem prób i błędów. Zgodnie z koncepcją pragmatyczną, człowiek pracuje najwydajniej, gdy jest wystarczająco elastyczny, aby płynnie i plastycznie wypróbowywał nowe pomysły. Dzięki temu może czerpać z szerokiej gamy schematów pojęciowych, wykorzystując te, które najlepiej pasują do danej sytuacji. Konkretna umiejętność analityczna przydatna w danej sytuacji może się bowiem okazać kompletnie bezużyteczna w innej sytuacji, niekoniecznie znacząco odmiennej. Należy wtedy sięgnąć po inną, bardziej użyteczną umiejętność. Dewey uważał, że taki rodzaj zręczności intelektualnej prowadzi do osiągnięcia założonych celów oraz do najbardziej racjonalnych i użytecznych rezultatów. Jest to jego zdaniem najlepsze rozumowanie, oparte na tzw. logice eksperymentalnej. Dla J. Deweya ludzkie rozumowanie jest eksperymentalnym procesem dociekania i refleksji (J. Dewey 1938: 101 i nast., 1910: 68 i nast.).

Zamiast koncentrować się na filozofii umysłu, tak jak zrobili to racjonaliści, J. Dewey postrzegał umysł ludzki w świetle codziennych doświadczeń i zorientowania ludzkiej wiedzy na cele lub na konsekwencje działań (J. Dewey 1938: 104). Wskazywał konieczność stawiania praktycznych, naturalnych pytań: „,co by się stało, gdybym to zrobił?”, „do czego miałbym się zobowiązać?” (R. Rorty 1982: 163). Jego zdaniem nie należy poszukiwać uniwersalnych prawd, lecz metod stosowanych tu i teraz, a będących najlepszymi dostępnymi metodami osiągania określonych wyników (J. Dewey 1938: 108). Takie stanowisko wskazuje na znaczące odejście od tradycyjnej epistemologii. Tam, gdzie szuka ona logicznych stałych, Dewey kategoryzuje doświadczenia w użyteczny i praktyczny sposób i identyfikuje następujące etapy rozumowania: (I) rozpoznanie nieokreślonej sytuacji; (II) zlokalizowanie problemu; (III) określenie rozwiązania problemu; (IV) rozumowanie dotyczące rozwiązania; (V) operacyjny charakter znaczenia faktów w rozwiązaniu problemu (J. Dewey 1938: 116).

Wspólna struktura lub wzorzec rozumowania obejmuje pięć logicznie odrębnych kroków, które można wykorzystać do ustalenia, czy podejmowane działanie będzie użyteczne, czy nie: (i) odczuwana trudność; (ii) jej lokalizacja i zdefiniowanie; (iii) opcje [możliwego] rozwiązania; (iv) rozumowanie o opcjach; (v) dalsza obserwacja i doświadczenie prowadzące do ich przyjęcia lub odrzucenia (J. Dewey 1910: 72). Kroki w tym procesie odzwierciedlają sposób, w jaki zazwyczaj człowiek obiektywnie i praktycznie myśli o problemach. Co istotne, Dewey nie proponuje przyjęcia nowego sposobu myślenia, lecz próbuje opisać ten sposób, w jaki człowiek zwykle myśli. Chce dzięki temu nakłonić odbiorcę do bardziej krytycznego spojrzenia na swoje analityczne nawyki, co z kolei sprawi, że będzie on bardziej kompetentny w stosowaniu analizy i bardziej precyzyjny w korzystaniu ze swoich umiejętności.

Elastyczności rozumowania prawniczego można stwierdzić analizując pracę prawnika nad problemem prawnym. Rozwiązanie problemu prawnego wymaga uwzględnienia trzech etapów rozumowania: diagnozowania, prognozowania i przygotowania strategii. Prawnicy diagnozują, co dzieje się teraz lub działo się w prze- 
szłości, prognozują, co wydarzy się w przyszłości oraz opracowują i wdrażają strategie mające wpływ na przyszłe wydarzenia. Prawnik diagnozuje, zastanawiając się, dlaczego doszło do określonych zdarzeń (Dlaczego klient jest bardziej zdenerwowany małym problem niż dużym?, Dlaczego usługa nie została zrealizowana na czas?, Dlaczego druga strona negocjacji nie jest w stanie zrozumieć, że propozycja jest dobra dla obu stron?). Prawnik prognozuje, jak inni będą reagować na zdarzenia (Jeśli klient wniesie pozew, kto wygra?, W jaki sposób druga strona odpowie na propozycję zakończenia negocjacji?).

Prawnik określa strategię, opracowując plan rozwiązania problemu. Doradzając klientowi, oferuje kilka opcji, spośród których klient może wybrać najbardziej dla niego odpowiednią. Przygotowując się do negocjacji, opracowuje strategię, która pozwoli drugiej stronie zgodzić się tak dalece, jak to możliwe na rozwiązania proponowane przez jego klienta (T.H. Amabile 1996: 119). W zależności od potrzeb, stosuje przy tym dwa rodzaje rozumowania: zbieżne lub rozbieżne (M. Gladwell 2008: 8689). Rozumowanie zbieżne zmierza do zawężenia problemu, dla znalezienia jedynej właściwej odpowiedzi. Zakłada ono istnienie zamkniętego katalogu odpowiedzi na dane pytanie. Rozumowanie rozbieżne jest jego przeciwieństwem: pociąga za sobą poszerzenie dociekania poprzez myślenie w kilku kierunkach jednocześnie, dla znalezienia większej liczby odpowiedzi (lub hipotez lub strategii). Zakłada ono istnienie wielu odpowiedzi na dane pytanie (J. Elkins 1996: 511-523).

Proces twórczy pracy prawnika można umownie podzielić na sześć etapów, zawierających diagnozę, prognozę i strategię (S. Krieger/ R. Neumann 2015: 35-36):

1. Rozpoznanie problemu i jego zdefiniowanie.

Ten etap rozpoczyna się od dostrzeżenia, że sprawy nie toczą się właściwie i odpowiada dostrzeżeniu „,niejasnej sytuacji” zgodnie z koncepcją Deweya. Prawnik dostrzega problem i jego zadaniem jest skupienie się na nim, zanim zacznie przysparzać kłopotów. Na tym etapie celowe jest aktywne poszukiwanie problemów, zamiast ich unikania.

2. Przygotowanie: gromadzenie i ocena informacji.

Ten etap obejmuje zidentyfikowanie odpowiednich regulacji prawnych i faktów w sposób otwarty. Wskazane jest aktywne podejście do problemu i agresywna wręcz ciekawość.

3. Generowanie opcji: hipotez lub potencjalnych rozwiązań.

$\mathrm{W}$ przypadku stawiania diagnozy, prawnik powinien wyobrazić sobie potencjalne wyjaśnienia dla zaistniałych zdarzeń. W przypadku stawiania diagnozy, prawnik powinien wyobrazić sobie potencjalne wizje przyszłości. Potencjalne diagnozy i prognozy są hipotezami o rozwiązaniach problemu prawnego. Im więcej hipotez lub rozwiązań uda się prawnikowi wygenerować, tym większy jest wachlarz opcji, z którego może on korzystać na późniejszych etapach. Na tym etapie należy tylko sporządzić listę, lecz nie weryfikować ani nie oceniać hipotez ani rozwiązań - to będzie kolejny krok. Produktywne i użyteczne przy generowaniu opcji jest rozumowanie rozbieżne.

4. Ocena opcji: hipotez lub potencjalnych rozwiązań.

Jeśli na poprzednim etapie prawnik dokonał diagnozy, powinien teraz przetestować każde możliwe wyjaśnienie, aby zobaczyć, co dokładnie z niego wynika. Jeśli 
prognozował, powinien teraz przetestować każdą potencjalną prognozę, aby oszacować prawdopodobieństwo jej wystąpienia. Jeśli tworzył strategie, jego zadaniem jest przetestowanie każdego planu pod kątem skuteczności: w jaki sposób najlepiej osiągnąć cele klienta, jaki jest koszt i jakie ryzyko? We wszystkich tych trzech działaniach należy szukać konkretnych faktów i wyjaśnień dla nich, dowodów i przepisów prawa. Należy odpowiedzieć na pytanie, co takiego potwierdza, że wyjaśnienie jest dokładne (w przypadku diagnozy), że prognoza jest trafna (w przypadku prognozy) lub że plan wpłynie na wydarzenia (w przypadku strategii)? Prawnik powinien również poszukiwać negatywnego dowodu, który mógłby wyeliminować wyłonione opcje z uwagi na niedokładność diagnozy albo nietrafność prognozy lub małe prawdopodobieństwo powodzenia strategii. Zasadne jest zadanie sobie następujących pytań: Jeśli moja hipoteza jest prawdziwa, co jeszcze musi być prawdą (lub fałszem)?, Jeśli moja strategia będzie działać, jakie fakty, dowody lub prawo już zaistniały (lub nie)?. Ocena opcji jest oparta na rozumowaniu zbieżnym, zmierzającym do wyeliminowania opcji niepraktycznych, niepopartych przez prawo lub fakty (szerzej: J.S. Dacey/ K.H. Lennon 1998).

5. Decydowanie.

Na tym etapie prawnik dokonuje wyboru najdokładniejszej diagnozy, najbardziej prawdopodobnej prognozy lub najbardziej skutecznej strategii.

6. Działanie.

Jeśli decyzja jest oparta na diagnozie lub prognozie, należy ją zakomunikować właściwym odbiorcom (na przykład klientowi) lub wykorzystać samodzielnie. Jeśli decyzja dotyczy wyboru strategii, należy ją wdrożyć.

W praktyce tych sześć etapów można segmentować jedynie stosując elastyczne podejście, a zgodnie z założeniami logiki eksperymentalnej, proces myślenia może zataczać kręgi. Na przykład podczas dokonywania oceny hipotezy, może okazać się, że potrzebne są dodatkowe informacje. Prawnik wraca wtedy do przygotowania (etap 2), aby pozyskać te informacje, a następnie przystępuje do oceny (etap 4). Po drodze możliwe jest generowanie innych, potencjalnych rozwiązań (etap 3). Działanie na rozwiązaniach (etap 6) może natomiast zainspirować do generowania opcji dla innych rozwiązań (etap 3). Przygotowanie (etap 2) i generowanie opcji (etap 3) często odbywają się w tym samym czasie, podobnie jak ocena opcji (etap 4) i podjęcie decyzji o wyborze jednej z nic (etap 5).

Największe wyzwanie stanowi generowanie i ocenianie opcji - częściowo dlatego, że wymagają one przeciwnych umiejętności. Aby wygenerować jak największą liczbę możliwych rozwiązań lub hipotez, należy pozbyć się zahamowań i dezaktywować sceptycyzm. Na tym etapie pomysły dobre pojawiają się równocześnie z pomysłami wadliwymi. Jednak przedwczesna ich krytyka może zablokować napływ pomysłów - wszystkich, zarówno dobrych, jak i złych - zanim do generatora dotrze ich potencjał (S. Krieger/ R. Neumann 2015: 82-83, 173). Sceptycyzm jest ceniony przez praktykę prawniczą. Jednak prawnik, który jest bardziej biegły w krytykowaniu pomysłów niż w ich tworzeniu, będzie mniej skutecznym narzędziem rozwiązywania problemów. Działaniem stojącym w opozycji do generowania opcji jest ich ocena. 
Wymaga ona bowiem cech, które mogłyby osłabić generowanie opcji: rygorystycznego sceptycyzmu, pragmatycznego poczucia realizmu, umiejętności precyzyjnego szacowania ryzyka i rozprawienia się z obawą, że pomysł może być radykalnie chybiony. Te same cechy, które należy wyłączyć, generując hipotezy i rozwiązania, trzeba następnie włączyć ponownie po złożeniu pełnego zakresu opcji i rozpoczęciu ich oceny. Podczas generowania opcji prawnik postępuje najlepiej, jeśli myśli swobodnie i toleruje pewien intelektualny chaos. Jednak podczas oceny powinien zmienić podejście i przyglądać się rozwiązaniom z zimnym realizmem tego, kto musi wziąć na siebie odpowiedzialność za sukces lub porażkę.

\section{Pragmatyczna komunikacja prawnicza}

Logika eksperymentalna sprzyja poszukiwaniu inkluzywnych rozwiązań problemów prawnych, uwzględniających szerokie spektrum różnorakich czynników. Taki wieloaspektowy problem moralny postawiła w swoich badaniach C. Gilligan, rozróżniając etykę sprawiedliwości i etykę troski (C. Gilligan 1993: 2639). Problem oparty był na następujących faktach: 1) żona Heinza jest chora, a jej życie można uratować tylko za pomocą leku, którego koszt przekracza możliwości finansowe Heinza i jego żony; 2) lokalny aptekarz nie chce obniżyć ceny leku. O rozwiązanie problem zwrócono się do dwojga jedenastoletnich dzieci, Jake'a i Amy, prosząc je od udzielenie odpowiedzi na hipotetyczne pytanie, czy Heinz powinien ukraść ten zbyt drogi lek, żeby uratować życie żony.

Dzieci rozwiązały zadany problem prawny i zakomunikowały swoje odpowiedzi na pytanie prawne zupełnie odmiennie. Jake odpowiedział, że Heinz powinien ukraść lek. Jego zdaniem ludzkie życie jest warte więcej niż pieniądze. Uważał, że aptekarz może zrekompensować sobie żądaną kwotę później od bogatych klientów, podczas gdy Heinz nie będzie mógł odzyskać swojej żony, jeśli ta umrze z powodu braku leku. Zdaniem Jake'a, jeśli Heinz zostanie schwytany, sąd prawdopodobnie go uniewinni. Jake stwierdził, że dylemat Heinza to „problem matematyczny z ludźmi”. Uzasadnił kradzież poprzez hierarchię dóbr: dostrzegł prawną potrzebę usprawiedliwienia kradzieży, zważył dobra i podjął decyzję o wyższości jednego dobra nad drugim. Amy odpowiedziała, że Heinz nie powinien ukraść leku. Uznała, że poza kradzieżą mogą istnieć inne sposoby na zdobycie leku, takie jak pożyczenie pieniędzy. Zdaniem Amy, ani Heinz nie powinien kraść leków, ani też jego żona nie powinna umrzeć. Gdyby Heinz ukradł lek, mógłby wprawdzie uratować swoją żonę, ale gdyby to zrobił, musiałby pójść do więzienia, a wtedy jego żona mogłaby rozchorować się jeszcze bardziej, a on nie mógłby się nią opiekować i zdobyć więcej dawek leku. Heinz powinien więc znaleźć inny sposób na zdobycie pieniędzy.

Odpowiedź Jake'a wyraźnie wynika z rozważań sylogistycznych. Natomiast Amy skupiła się na relacjach między Heinzem i jego żoną oraz między Heinzem a aptekarzem. Dostrzegła, że żona potrzebuje Heinza a Heinz troszczy się o swoją żonę. Starała się odpowiedzieć na potrzeby aptekarza w taki sposób, aby podtrzymać, a nie zerwać więź między małżonkami. Amy oparła swój osąd moralny na przekonaniu, że jeśli ktoś ma rzecz, która utrzyma inną osobę przy życiu, to nie jest właściwe, aby mu jej nie dał. Jej zdaniem problem nie polega na tym, że aptekarz dochodzi swoich praw, 
ale na braku jego reakcji. Komunikując wybrane rozwiązanie, Jake odwoływał się do równości, wzajemności, sprawiedliwości i praw. Amy wskazywała zaś na związek, niewyrządzanie krzywdy, opiekę i relację. Amy poszukiwała różnych opcji stosując rozumowanie rozbieżne: Czy Heinz i aptekarz szukają innych możliwości, takich jak transakcje kredytowe?, Dlaczego Heinz i aptekarz nie mogą usiąść wspólnie i porozmawiać o problemie, tak aby aptekarz zrozumiał znaczenie życia żony dla Heinza? (patrz dyskusję: C. Gilligan 2014: 89-106).

Rozumowanie Amy może wydawać się naiwne, jednak w świetle logiki eksperymentalnej to ją należy uznać za skuteczniejszą w rozwiązaniu problemu. Jake posłużył się zbieżną, hierarchiczną logiką, określającą, które dobro ma wyższą rangę. Amy intensywnie szukała rozwiązania problemu, a nie sposobu ocenienia, kto ma rację. Dzieciom zadano jedno, to samo pytanie, jednak każde z nich usłyszało co innego: Jake usłyszał je jako pytanie o hierarchiczną ocenę wyników, natomiast Amy - jako pytanie o rozwiązanie problemu. Amy dostrzegła, że rozwiązanie problemu niekoniecznie wymagało rozstrzygnięcia, czyje prawa są ważniejsze. Oparła się więc ograniczeniom nałożonym przez pytającego. Wygenerowała bogatsze rozwiązanie, dzięki temu, że nie poddała się uprzedzeniom wynikającym ze sposobu sformułowania pytania. Amy zastosowała rozwiązanie inkluzywne - rozwiązała problem, zaspokajając potrzeby wszystkich zaangażowanych osób. Skupienie się na relacjach pomogło jej zrozumieć, że Heinz nie uwolni się od swojego dylematu, dopóki aptekarz nie będzie wolny od swojego. Znalezienie takiego rozwiązania możliwe jest w oparciu o założenia logiki eksperymentalnej, wymyka się natomiast ograniczeniom wynikającym z założeń logiki formalnej.

\section{Posumowanie}

Pojęcie logiki eksperymentalnej i procesu, który Dewey zidentyfikował jako serce tej logiki, obejmuje sposoby systematycznego angażowania się w rozumowanie prawnicze mające na celu uzyskanie efektywnych rezultatów. Atrakcyjność tej teorii wynika z takiego jej zaprojektowania, aby dawała użyteczne efekty i umożliwiła rozwiązywanie praktycznych problemów prawnych. Naturalnie rozumujemy tak, aby osiągać praktyczne rezultaty. Jednak świadomość możliwości rozpoznania i wyodrębnienia części procesu rozumowania, powinna nam pomóc w dokonywaniu bardziej systematycznej, bardziej celowej i precyzyjnej analizy prawnej. Mówimy przy tym nie o rozumowaniu linearnym, lecz o rekursywnym procesie, wymagającym zapętlania początkowych konceptualizacji i przeprowadzania dodatkowych badań w miarę posuwania się naprzód. Taki proces rozumowania umożliwia prawnikowi korzystanie ze wszystkich narzędzi, zarówno wyuczonych na studiach prawniczych, jak i pozyskanych w trakcie praktyki zawodowej w miarę rozwiązywania kolejnych problemów prawnych.

Pragmatyczne rozumowanie prawnicze pozwala na elastyczne podejście do problemów prawnych. Inaczej niż logika formalna oparta na sylogizmie ,jeżeli - to”, ten rodzaj analizy daje możliwość dokonywania wyboru efektywnych narzędzi rozumowania i komunikowania się, dostosowanych do okoliczności danej sprawy. Prawnik, 
który chce wyjść poza myślenie matrycowe, musi rozwinąć pewną mentalną i praktyczną zwinność. Zrozumienie i zastosowanie logiki eksperymentalnej Johna Deweya pozwala na uzyskanie tej zwinności. Postulowana przez niego koncepcja pragmatycznego rozumowania prawniczego zakłada, że kreatywność i subiektywność są podstawą złożonego systemu instytucji prawnych. Inne systemy rozumowania prawniczego usiłują wyeliminować te aspekty, konstruując stricte „,naukowy” system teorii prawa (B. Bix 2004: 35, 59-60). Złożone rozumowanie ludzkie, w każdej dziedzinie, także prawnej, jest jednak wielopłaszczyznowe i pragmatyczne, w najpełniejszym znaczeniu tych wyrażeń.

Wyniki pracy prawnika zależą nie tylko od jego wiedzy o prawie, lecz również od umiejętności, których nie sposób nauczyć się na studiach prawniczych: wyczucia, jak klient zareaguje na problem i propozycje jego rozwiązania, przewidywania, jaką decyzję podejmie sędzia oraz oceny, jak klienci, sędziowie, świadkowie i przeciwnicy oraz ich pełnomocnicy odpowiedzą na podjęte działania. Rozumowanie oparte na założeniach logiki formalnej jest niewątpliwie niezbędne w pracy prawnika. Nie mniej wartościowa i potrzebna jest jednak inteligencja emocjonalna i oparte na niej kompetencje, zwłaszcza empatyczne zrozumienie ludzkiej natury. Rozwiązanie problemu musi uwzględniać wszystkie jego aspekty, nie tylko jego część formalną. W rozumowaniu prawniczym powinno się znaleźć miejsce dla elementów logiki eksperymentalnej z jej elastycznym i stricte użytkowym podejściem, negującym całkowicie dychotomię między teorią a praktyką.

\section{Bibliografia}

Amabile, T.H. (1996), Creativity in Context: Update to the Social Psychology of Creativity. Londyn.

Bix, B. (2004), Jurisprudence: Theory and Context. Durham.

Dacey, J.S./ K.H. Lennon (1998), Understanding Creativity: The Interplay of Biological, Psychological and Social Factors. San Francisco.

Dewey, J. (1910), How We Think. Boston, New Yourk. Chicago. (URL https://archive.org/stream/howwethink000838mbp/howwethink000838mbp_djvu.txt]. [Pobrano 23.01.2020].

Dewey, J. (1924), Logical Method and the Law, (w:) „Cornell Law Review” 10 (17), $17-27$.

Dewey, J. (1938), Logic: The Theory of Inquiry. New York. (URL https://archive.org/stream/JohnDeweyLogicTheTheoryOfIn-

quiry/\%5BJohn_Dewey\%5D_Logic_-_The_Theory_of_Inquiry_djvu.txt). [Pobrano 23.01.2020].

Dyrda, A. (2018), Realizm prawniczy a pozytywizm prawniczy, (w:) „AVANT” 11(1). (DOI: 10.26913/90102018.0103.0004). [Pobrano 23.01.2020].

Elkins, J. (1996), Thinking Like a Lawyer: Second Thoughts, (w:) „Mercer Law Review" 47, 511-523. 
Gilligan, C. (1993), In a Different Voice: Psychological Theory and Women's Development. Cambridge.

Gilligan, C. (2014), Moral injury and the ethic of care: Reframing the Conversation about Differences, (w:) ,Journal of Social Philosophy” 45(1), 89-106.

Gladwell, M. (2008), Outliers: The Story of Success. Boston.

Holmes, O.W. Jr. (1991), The Common Law. Mineola/New York.

Krieger S./ R. Neumann (2015), Essential Lawyering Skills. New York.

Levy, B.H. (1991), Anglo-American Philosophy of Law: An Introduction to Its Development and Outcome. New Jersey.

MacCormick, N. (1983), On Legal Decisions and Their Consequences: From Dewey to Dworkin, (w:) „New York University Law Review” 58, 239-255.

Mendell, M. (1994), Dewey and the Logic of Legal Reasoning, (w:) „Transactions of the Charles S. Peirce Society", 30(3), 575-635.

Muyumb, W. (2014), „All safety is an illusion”: John Dewey, James Baldwin, and the Democratic Practice of Public Critique, (w:) Trained Capacities: John Dewey, Rhetoric, and Democratic Practice. Columbia.

Neustadt R.E./ E.R. May (1986), Thinking in Time: The Uses of History for DecisionMakers. New York.

Osiejewicz, J. (2020), Transnational Legal Communication: Towards Comprehensible and Consistent Law, (w:) „Foundations of Science”. (URL https://doi.org/10.1007/s10699-020-09655-3). [Pobrano 17.03.2020].

Payton, S. (1985), Is Thinking Like a Lawyer Enough?, (w:) „University of Michigan Journal of Law Reform" 18, 233-236.

Rand, J.W. (2003), Understanding Why Good Lawyers Go Bad: Using Case Studies in Teaching Cognitive Bias in Legal Decision-Making, (w:) „Clinical Law Review" 9, 751-752.

Rorty, R. (1982), Consequences of Pragmatism: Essays 1972-1980. Minneapolis. 